(C) 2014

Маслиёв С. В., кандидат сельскохозяйственных наук

Луганский национальный университет имени Тараса Шевченко

\title{
УРОЖАЙНОСТЬ САХАРНОЙ И ЛОПАЮЩЕЙСЯ КУКУРУЗЫ ПРИ ВОЗДЕЛЫВАНИИ БЕССМЕННО И В СЕВООБОРОТАХ
}

\section{Рецензент - доктор сельскохозяйственных наук М. В. Орешкин}

\begin{abstract}
Подано результати багаторічних польових дослідів про урожайність початків иукрової та зерна розлусної кукурудзи різних сортів $і$ гібридів залежно від попередників у польових та овочевих сівозмінах, а також беззмінних посівах. Надані рекомендації по внесенню мінеральних добрив та строків сівби. Установлено, щчо кращими попередниками для цุих підвидів кукурудзи в польових сівозмінах $є$ гороховівсяна суміш на зелений корм та пшениця озима після пару, а в овочевих - огірки, цибуля, томати, рання картопля та кабачки, після яких урожайність початків иукрової кукурудзи досягає 8,5-9,5 m/2а, зерна розлусної-2,2-2,9 $\mathrm{m} / 2$.
\end{abstract}

Ключові слова: попередники, урожайність, початки, иукрова кукурудза, зерно, розлусна кукурудза.

Постановка проблемы. Последние годы в Украине существенно расширились площади посевов сахарной и лопающейся кукурузы для пищевых целей. Однако урожайность зерна и початков ее все еще остается невысокой вследствие того, что в практике не всегда уделяется надлежащее внимание предшественникам сахарной и лопающейся кукурузы.

Анализ последних достижений и публикаций, в которых основано решение данной проблемы. Среди агротехнических мероприятий, направленных на повышение урожайности кукурузы для пищевых целей, важнейшее значение имеет правильное размещение ее в севооборотах [2-5, 7-10]. Нарушение севооборотов, пренебрежение элементарными требованиями к чередованию культур часто приводит не только к непоправимым потерям урожая кукурузы, но и нарушению всей системы земледелия и снижению плодородия почвы. Рациональное же сочетание кукурузы с другими культурами повышает не только урожайность початков и зерна кукурузы, но и эффективность всех агроресурсов, увеличивает общую продуктивность севооборота, улучшает использование влаги, питательных веществ, ведет к повышению плодородия почв [4, 5, 7-10].

Цели исследований. Нами изучалось влияние различных предшественников полевого и овощного севооборотов, а также бессменного выра- щивания кукурузы на урожайность початков сахарной и зерна лопающейся подвидов на пищевые цели в Левобережной части Степи Украины.

Задачи исследований: показать результаты многолетних опытов влияния различных предшественников полевого и овощного севооборотов, а также бессменного выращивания кукурузы на урожайность початков сахарной и зерна лопающейся кукурузы. Сделать выводы и дать предложения по наилучшим предшественникам в различных севооборотах, по оптимальной обработке почвы, исходя из проведенных исследованний.

Объекты, методика и условия проведения исследований. Экспериментальные работы проводились в течение 2006-2013 гг. в Старобельском опытном хозяйстве ЛНУ им. Т. Шевченко и фермерском хозяйстве «Луна» Старобельского района, расположенных в степной северноцентральной умеренно засушливой подзоне Левобережной степной зоны. Почвы опытных участков - черноземы типичные с содержанием гумуса в пахотном слое $(3,5-3,6 \%)$, гидролизованного азота (10,4-11,2 мг на 100 г почвы), подвижного фосфора (10,1-10,8 мг на 100 г почвы) и обменного калия (14,4-15,3 мг на 100 г почвы). Опыты размещались в овощном севообороте на пойменных землях реки Айдар и в полевом севообороте. Обработка почвы включала лущение стерни, вспашку на 20-22 см, весеннее боронование и 2-3 допосевные культивации. Удобрения нормой $\mathrm{N}_{60} \mathrm{P}_{60} \mathrm{~K}_{40}$ вносили под основную обработку почвы и как подкормку. Сев кукурузы проводили при прогревании 0-10 см слоя почвы до $12-14{ }^{\circ} \mathrm{C}$. Густоту стояния растений формировали из расчета 50 тис/га. Междурядные культивации осуществляли в фазу 4-5 и 7-8 листьев у кукурузы. Закладку опытов, учеты, наблюдения проводили по общепринятым и специальным методикам $[1,6]$.

Результаты исследований. Было установлено, что в овощных севооборотах, хорошо обеспеченных влагой и питательными веществами на протяжении всей вегетации кукурузы, роль предшественников в формировании урожайности несколько нивелировалась. 
СІЛЬСЬКЕ ГОСПОДАРСТВО. РОСЛИННИЦТВО

1. Урожайность початков сахарной кукурузы в зависимости от предчественников, 2007-2010 z2.

\begin{tabular}{|c|c|c|}
\hline \multirow{2}{*}{ Предшественники } & \multicolumn{2}{|c|}{ Урожайность початков, т/га } \\
\cline { 2 - 3 } & в обертках & без оберток \\
\hline Горох, овес на з/корм. & 8,76 & 6,12 \\
\hline Кукуруза зерновая & 7,96 & 5,50 \\
\hline Тыква, кабачки & 8,47 & 5,89 \\
\hline Картофель & 8,51 & 6,11 \\
\hline Свекла & 6,53 & 4,47 \\
\hline Лук & 8,55 & 5,83 \\
\hline Капуста & 6,86 & 4,62 \\
\hline Томаты & 8,28 & 5,66 \\
\hline Морковь & 6,71 & 4,60 \\
\hline Огурец & 8,79 & 6,15 \\
\hline НСР & 5,22 \\
\hline Промежут. посев после ранних овощных* & 7,58 & 0,52 \\
\hline * Данные за 2007, 2009, 2012 гг. \\
\hline
\end{tabular}

2. Урожайность початков сахарной и зерна лопающейся кукурузы (m/za) в различных звеньях полевого севооборота, 2011-2013 z2.

\begin{tabular}{|c|c|c|c|}
\hline \multirow{2}{*}{ Звенья севооборота } & \multicolumn{2}{|c|}{$\begin{array}{c}\text { Початков сахарной кукурузы } \\
\text { гибрида Конкурент }\end{array}$} & $\begin{array}{c}\text { Зерна лопающейся } \\
\text { кукурузы гибрида } \\
\text { Гостинец }\end{array}$ \\
\cline { 2 - 4 } & в обертках & кондиционных & \\
\hline Пар - пшеница - кукуруза (контроль) & 7,98 & 6,35 & 3,76 \\
\hline Горох - пшеница - кукуруза & 7,36 & 5,78 & 3,34 \\
\hline Кукуруза - ячмень - кукуруза & 6,21 & 4,82 & 2,90 \\
\hline Подсолнечник - ячмень - кукуруза & 5,44 & 4,13 & 2,51 \\
\hline HСР $_{05}$ & 0,61 & 0,47 & 0,22 \\
\hline
\end{tabular}

\section{3. Урожайность зерна и початков (m/2a) пищевых подвидов кукурузы после различных предчественников, 2007-2010 г2.}

\begin{tabular}{|c|c|c|c|}
\hline Предшественники & $\begin{array}{c}\text { Кремнисто-зубовидная } \\
\text { (Днепровский } 310 \mathrm{MB}), \\
\text { контроль } \\
\end{array}$ & $\begin{array}{c}\text { Лопающаяся } \\
\text { (Днепровский 925) }\end{array}$ & $\begin{array}{c}\text { Сахарная } \\
\text { (Ароматная) }\end{array}$ \\
\hline \multicolumn{4}{|c|}{ Полевой севооборот } \\
\hline Озимая пшеница & 5,47 & 2,23 & 7,63 \\
\hline Горох + ячмень на 3/корм & 7,05 & 2,66 & 8,47 \\
\hline Кукуруза зерновая & 4,83 & 2,10 & 6,28 \\
\hline Озимые на з/корм & 7,28 & 2,86 & 8,45 \\
\hline $\mathrm{HCP}_{05}$ & 0,64 & 0,11 & 0,88 \\
\hline \multicolumn{4}{|c|}{ Овощной севооборот } \\
\hline Свекла столовая & - & 1,40 & 7,22 \\
\hline Картофель ранний & - & 2,57 & 8,88 \\
\hline Капуста поздняя & - & 1,29 & 7,19 \\
\hline Лук репчатый & - & 2,63 & 9,28 \\
\hline $\begin{array}{c}\text { Бахчевые } \\
\text { (кабачок, тыква) }\end{array}$ & - & 2,78 & 9,46 \\
\hline $\mathrm{HCP}_{05}$ & - & 0,35 & 0,69 \\
\hline $\begin{array}{c}\text { Поукосно после ржи ози- } \\
\text { мой на зеленый корм* }\end{array}$ & - & $3,11 / 28,8^{* *}$ & 8,35 \\
\hline $\begin{array}{l}\text { Промежуточный посев } \\
\text { после ранних овощных* }\end{array}$ & - & $3,29 / 30,3^{* *}$ & 8,77 \\
\hline $\begin{array}{c}\text { Промежуточный посев } \\
\text { после зеленных культур * }\end{array}$ & - & $2,62 / 32,6^{* *}$ & 8,91 \\
\hline $\mathrm{HCP}_{05}$ & - & 0,26 & 0,42 \\
\hline
\end{tabular}

Примечания: * данные за 2010-2012 гг.

** в числителе - урожайность, в знаменателе - влажность зерна при уборке. 


\section{СІЛЬСЬКЕ ГОСПОДАРСТВО. РОСЛИННИЦТВО}

Урожайность початков сахарной кукурузы после основных овощных, бахчевых, некоторых зерновых и кормовых культур была практически одинаковой и достигала $8,28-8,79$ т/га в обертках и 5,66-6,15 т/га без оберток. Уменьшение ее отмечалось лишь после свеклы, моркови и капусты, что объясняется, очевидно, отрицательным влиянием на кукурузу послеуборочных остатков и корневых выделений этих культур (табл. 1).

В отдельные годы, особенно засушлывые, лучшими предшественниками сахарной кукурузы были ранний картофель и лук, несколько худшими - горохо-овсяные смеси на зеленый корм и огурец, тогда как наихудшими - свекла и капуста.

Эффективным звеном полевого севооборота для возделывания зерновой кукурузы на пищевые цели было такое звено, как черный пар - пшеница озимая - кукуруза, в котором в наилучшей степени обеспечивалось подавление сорняков и достигалась максимальная урожайность зерна (табл. 2).

При посеве сахарной кукурузы в звеньях севооборота горох - пшеница озимая урожайность кондиционных початков снижалась в сравнении с контролем на 0,57 т/га, кукуруза - ячмень яровой кукуруза - на 1,53 , подсолнечник - ячмень кукуруза - на 2,22 т/га. Еще более заметным было снижение урожайности в этих звеньях в посевах лопающейся кукурузы. Если на контрольном варианте урожайность зерна ее достигала 3,76 т/га, то в звене подсолнечник - ячмень - кукуруза - лишь 2,51 т/га или на $33 \%$ ниже, чем на контроле.

В полевых севооборотах максимальная урожайность початков сахарной $(8,45-8,47$ т/га) и зерна лопающейся кукурузы (2,66-2,86 т/га) была получена при размещении после озимой ржи и горохо-овсяной смеси на зеленый корм, а в овощных орошаемых (соответственно 8,88-9,46 и 2,57-2,78 т/га) - еще и после бахчевых, репчатого лука, раннего картофеля (табл. 3).

После других предшественников урожайность сахарной и лопающейся кукурузы была значительно ниже и не превышала соответственно початков молочного состояния зерна 6,28-7,19 т/га и зерна 1,292,10 т/га. Разница в урожайности кукурузы после различных предшественников объяснялась, очевидно, разной степенью удобренности предшествующей культуры и степенью использования ею питательных веществ почвы, а также эффективностью борьбы с сорняками в ее посевах.

На орошаемых и пойменных землях пищевые подвиды кукурузы при выращивании их на постоянных участках в бессменных посевах, при достаточной обеспеченности питательными веществами, тщательной глубокой заделке пожни- вных остатков и эфективной защите посевов от специализированных вредителей и болезней обеспечивались относительно высокие урожаи зерна лопающейся и початков сахарной кукурузы (табл. 4).

Так, на удобренных вариантах урожайность початков сахарной кукурузы при вспашке почвы на 22-24 см в среднем за 4 года снизилась всего лишь на 0,43 т/га, а лопающейся кукурузы - на 0,2 т/га, что было в пределах ошибки опыта, тогда как по мелкой обработке почвы на 10-12 см снижение урожайности как початков сахарной, так и зерна лопающейся кукурузы было более существенным и достигало соответственно 2,12 и $1,15 \mathrm{~T} / \mathrm{ra}$.

Но особенно заметным было снижение урожайности кукурузы на вариантах без удобрений. Для початков сахарной кукурузы оно достигало 2,87 т/га, а лопающейся - 2,04 т/га при вспашке почвы на 20-24 см и на 2,86 и 1,89 т/га при мелкой обработке почвы на 10-12 сантимертів.

В целом по вспашке урожайность початков сахарной и зерна лопающейся кукурузы на удобренных участках в первые годы закладки опыта была выше на 34-36 \%, а по мелкой обработке на $38-40 \%$, а через четыре года бессменного выращивания кукурузы урожайность увеличилась на 52-78 и 50-77 \%, что указывает на возрастание с годами роли минеральных удобрений при выращивании бессменных посевов как сахарной, так и лопающейся кукурузы.

В качестве поукосной, пожнивной и промежуточной культуры кукурузу размещали после озимых на зеленый корм, однолетних и многолетних трав, зеленных и ранних овощей.

Наиболее высокая эффективность этих посевов достигалась при выращивании сахарной кукурузы. Урожайность ее достигала 8,35-8,91 т/га, причем максимальной она была после ранних зеленных культур (укроп, салат, кресс-салат горчица и др.), но фазы молочного состояния зерна она достигала на 11-16 дней позже, чем после озимой ржи на зеленый корм и на 7-9 дней позже, чем после ранних овощных культур (редис, лук и чеснок на перо, скорцонера и др.).

В то время как поукосные и промежуточные посевы лопающейся кукурузы хотя и обеспечивали высокую (на уровне 2,62-3,29 т/га) урожайность зерна, но влажность его при поздних сроках уборки достигала 29-33 \% и более, что в дальнейшем затрудняло ее хранение или несло за собой дополнительные затраты на сушку початков. 
СІЛЬСЬКЕ ГОСПОДАРСТВО. РОСЛИННИЦТВО

\section{4. Урожайность зерна лопающейся (гибрид Вулкан) и початков сахарной кукурузы (гибрид Ароматная) (m/2a) при выращивании в бессменных посевах (2010-2013 22.)}

\begin{tabular}{|c|c|c|c|c|}
\hline \multirow{2}{*}{ Годы } & \multicolumn{2}{|c|}{ Без удобрений } & \multicolumn{2}{c|}{$\mathrm{N}_{90} \mathrm{P}_{60} \mathrm{~K}_{30}$} \\
\cline { 2 - 5 } & сахарная & лопающаяся & сахарная & лопающаяся \\
\hline \multicolumn{5}{|c|}{ Вспашка на 22-24 см } \\
\hline 2010 & 7,14 & 3,02 & 9,36 & 4,70 \\
\hline 2011 & 6,53 & 2,61 & 9,05 & 4,28 \\
\hline 2012 & 5,81 & 1,69 & 8,56 & 4,92 \\
\hline 2013 & 4,27 & 0,98 & 8,93 & 4,50 \\
\hline \multicolumn{5}{|c|}{ Мелкая обработка почвы на $10-12$ см } \\
\hline 2010 & 6,08 & 2,65 & 8,47 & 4,00 \\
\hline 2011 & 5,33 & 2,16 & 8,18 & 3,77 \\
\hline 2012 & 4,12 & 1,24 & 7,69 & 3,26 \\
\hline 2013 & 3,26 & 0,76 & 6,35 & \\
\hline
\end{tabular}

Поэтому поукосные и пожнивные посевы кукурузы на сухое зерно, а в особенности лопающейся, можно проводить только при условии, когда после уборки первой культуры останется не менее 115-120 безморозных дней с суммой эффективных температур $1200-1250^{\circ} \mathrm{C}$, необходимых для полного завершения вегетационного периода раннеспелых и среднеранних гибридов.

Вывод. Лучшими предшественниками пищевых подвидов кукурузы в полевых севооборотах

\section{БИБЛИОГРАФИЯ}

1. Доспехов Б. А. Методика полевого опыта / Б. А. Доспехов. - М. : Агропромиздат, 1986. $351 \mathrm{c}$.

2. Конопля M. I. Екологічно безпечні технологічні проекти вирощування харчової кукурудзи в умовах північного Степу України / [M. І. Конопля, С. В. Маслійов, В. А. Шевченко та ін.]. - Луганськ : Шико, 2008. - 24 с.

3. Конопля M. I. Розлусна кукурудза на Сході України / М. І. Конопля, С. В. Маслійов. - Луганськ : Шлях, 1999. - 154 с.

4. Лебідь С. М. Спогадаймо недавню славу качанистої / Є. М. Лебідь, В. С. Циков // Зерно і хліб. - 2004. - №2. - С. 32-34.

5. Лебедь $E$. М. Влияние предшественников на урожайность кукурузы / [Е. М. Лебедь, А. М. Суворинов, В. А. Медведь и др.] // Бюл. Института кукурузы УААН. - Днепропетровск, 1992. Вып. 75. - С. 35-39. являются пшеница озимая (особенно в звене пар - пшеница - кукуруза) и однолетние травы на зеленый корм, а в овощных - бахчевые, репчатый лук, ранний картофель. Высокую урожайность сахарная кукуруза обеспечивает в промежуточных посевах после ранних зеленных культур. В повторных посевах выращивание пищевых подвидов кукурузы возможно только при внесении удобрений и глубокой обработке почвы.

6. Основы опытного дела в растениеводстве / [В. Е. Ещенко, М. Ф. Трифонова, П. Г. Копытко и др.] - М. : Колос, 2009. - 268 с.

7. Пащенко Ю. М. Адаптивні і ресурсозбережні технології вирощування гібридів кукурудзи / Ю. М. Пащенко, В. М. Борисов, О. Ю. Шишкіна. Д. : АРТ-ПРЕС, 2009. - С. 55-70.

8. Циков B. C. Кукуруза на пищевые и лекарственные цели: производство, использование / В. С. Циков, Н. И. Конопля, С. В. Маслиев. Луганск : Шико, 2013. -232 с.

9. Циков В. С. Агроэкологические приемы выращивания пищевой кукурузы / [В.С. Циков, Н. И. Конопля, С. В. Маслиёв, Н. А. Орлянский]. Воронеж : Феникс, 2014. - 204 с.

10. Юмагулов Г. Л. Сахарная кукуруза в Подмосковье / Г. Л. Юмагулов // Кукуруза и сорго. 1999. - №3. - C. 19-21. 